\title{
The Destruction of Value
}

\section{The process of bankruptcy destroyed value}

Under its dramatic headline, 'Lehman's chaotic bankruptcy filing destroyed billions in value', the Wall Street Journal proclaimed that a 'less hurried Chapter 11 bankruptcy filing would have preserved tens of billions of dollars of value'. A study carried out by the advisory firm Alvarez \& Marsal argued that 'an orderly filing would have enabled Lehman to sell some of its assets outside the federal court bankruptcy protections and would have given it time to unwind its derivatives portfolio in a way that might have preserved value.'

Alvarez \& Marsal's co-founder and co-CEO, Bryan Marsal, was appointed CEO of Lehman Brothers, overseeing the largest bankruptcy in America history, at about $10.30 \mathrm{pm}$ on Sunday 14 September 2008, just hours before Lehman actually filed for bankruptcy. He arrived at 8.30 am the following morning and saw everyone leaving with boxes. In December 2008, he estimated that the total value destruction would be between $\$ 50$ and $\$ 75 \mathrm{bn}$, once losses from derivatives trades and asset impairment were combined. Lehman had 1.2 million derivative contracts, with a notional value of $\$ 39$ trillion. 'That is what the Fed and Treasury did not understand - the worldwide implications of the derivative book.' In an interview he gave in July 2013, he said that 'in the Lehman matter, the creditors lost $\$ 150 \mathrm{bn}$. That's a $\$ 150 \mathrm{bn}$ of value out of pension funds and savings. ${ }^{2}$

International derivative contracts were not the only problem. Lehman had over 7,000 legal entities in over 40 countries, of which 209 were registered subsidiaries, in twenty-one countries. Its collapse resulted in over 75 separate and distinct bankruptcy proceedings immediately, and affected thousands of financial market participants through its wide range of contracts. These included mortgage banks for whole residential mortgage loans; other banks/dealers for market making, firm finance, OTC derivatives; hedge funds for prime brokerage, custody, trade finance, OTC derivatives, secondary trading and MBSs and 
CMBSs; sovereign and municipal debt issuers for credit and interest rate derivatives and the primary dealer; money market funds for commercial paper; insurance companies for debt and equity securities, commercial paper, OTC derivatives and MBSs and CMBSs; and finally corporate issuers for debt, equity and OTC derivatives. Many clients and counterparties found themselves exposed to multiple Lehman Brothers entities in various legal jurisdictions, with different bankruptcy and insolvency laws and contractual protections and remedies.

Lehman Brothers International (Europe) based in London also suffered from the nightly sweep. Like so many global corporations, Lehman Brothers in New York swept the cash from its regional operations back to New York, and released funds the next day. The Friday sweep on 12 September 2008 had taken $\$ 8$ bn out of the London-based company. Without cash, the business would not be able to meet its financial obligations on Monday morning, 15 September. An apparently thriving business of over 5,000 staff and investments worth billions of dollars was broke. But the bank's European team were ahead of their American holding company. On Friday 12 September 2008, Lehman's shares closed at $\$ 4.22$ - down more than 75 per cent from the beginning of the week. Everyone knew about the meetings taking place in New York, but 'the bank's European team felt they ought to develop a just-in-case plan should their US counterparts be unable to pull off a deal', so Tony Lomas, head of PwC's restructuring and insolvency practice, bringing a small team with him, was invited to attend the firm's office in Canary Wharf. He did not leave until Tuesday, when the team took over the European part of the bankruptcy. They had learnt about the cash sweep on Sunday evening, and they needed to get the administration orders that would appoint them as administrators before the London markets opened at 8.00 am on the Monday. They succeeded with four minutes to spare. The Financial Services Authority was on hand when the judge signed the administration orders, since the bank was responsible for 12 per cent of all the trades on the London Stock Exchange. Its prime brokerage business, serving the hedge funds, was one of the largest in London, holding \$40bn of client assets.

The sudden announcement of the bankruptcy, however much the markets might have anticipated it, meant that the previous three days' trades had not been finally settled or completely recorded in the bank's systems. The volume of trades had rapidly increased, since no one wanted to be caught holding them. This meant that the stock exchanges began to work through 
the deals to reach settlement, and securities traded by Lehman were simply left alone.

Then there were the cancellations, when counterparties such as banks or hedge funds with whom Lehman had traded rushed to trigger legal clauses to extricate themselves from some deals. Thousands of e-mail cancellations hit the bank. Either for itself or its clients, Lehman held securities such as stocks, currencies, commodities, bonds and various derivatives ... Monday brought the realisation that the broken deals meant that many hedges were no longer in place. $^{3}$

There were both winners and losers in those frantic days. Lehman won in some instances, as the bank had some long positions when the market went up, and had some short positions, when the market went down. 'For some positions that we moved', according to $\mathrm{PwC}$, 'we made gains that exceeded the entire earnings of one of the divisions last year.' The markets were extremely volatile in the days following Lehman's bankruptcy.

If winding up Lehman Europe created chaos, the US bankruptcy was even worse. There is an interesting and important difference between the board of Lehman Brothers (Europe), whose board met on the Sunday and called in PwC in preparation for a possible bankruptcy so that they were prepared before the markets opened on Monday 15 September, whereas the board of Lehman Brothers Holding Company had to be told, in effect, to commence bankruptcy proceedings. These turned out to be even more chaotic than those in London.

Harvey Miller, whose firm had represented Lehman on various legal matters since 1984, was summoned to the New York Federal Reserve late on Sunday afternoon, 14 September with other Lehman executives and officials from the Federal Reserve, the Treasury and the SEC to hear Tom Baxter, general counsel for the FRBNY announce that since the Barclays deal had failed, Lehman had to file for bankruptcy by midnight. Miller argued: 'You don't realize what you're saying. It's going to have a disabling effect on the markets and destroy confidence in the credit markets. If Lehman goes down, it will be Armageddon.5 He was right. Later in the course of the bankruptcy proceedings, he stated that he believed that the regulators could have stepped in, not necessarily to save Lehman, but to head off the meltdown that followed: 'They totally missed it.' He added: 'When companies rushed to terminate contracts with Lehman, investor confidence plummeted in just about everything - securities and the markets they trade on, corporate debts and the assets backing them ... demand for corporate debt utterly evaporated.' In the hearing in mid-September, he said that 
'events moved with a velocity that almost defies comprehension', adding that in one 24-hour period, Lehman lost \$1.6bn when the Chicago Mercantile Exchange closed out all Lehman's positions. ${ }^{6}$

In his evidence to the Financial Crisis Inquiry Commission, Miller provided more of the background to 'Armageddon'. On 15 September 2008, Lehman was party to over 10,000 derivatives contracts relating to about 1.7 million transactions, and a major participant in hundreds of substantial real estate and loan transactions. To a limited extent, Barclays' purchase of Lehman's North American Capital Markets business to BarCap for $\$ 1.75$ bn plus $\$ 250 \mathrm{~m}$. in cash for its trading assets valued at $\$ 72 \mathrm{bn}$ and trading liabilities worth $\$ 68 \mathrm{bn}$, within five days of the beginning of bankruptcy proceedings, helped. Miller described the sale as being 'of enormous benefit to the nation. We saved a business that would have put 10,000 people out of work if it hadn't been sold.' Miller argues that

A government sponsored plan to support an orderly wind-down of Lehman's business over a reasonable period of time might have negated or substantially eliminated the risks to the financial system and the public that were actually encountered. It has been estimated by some commentators that a government sponsored wind-down with limited guarantees, might have cost $\$ 40$ to $\$ 50 \mathrm{bn}$. That cost would have been far less than the initial $\$ 700 \mathrm{bn}$ of value that disappeared during the first week of Lehman's Chapter 11 bankruptcy case and the additional costs to the economy that followed in subsequent weeks. ${ }^{8}$

In his testimony to the House of Representatives Committee on the Judiciary, Miller pointed out that the whole point of the Chapter 11 bankruptcy is to provide an automatic stay so that the debtor and its creditors can try to preserve the value of the debtor's assets and possibly increase their value, which would benefit all stakeholders. The problem was not only the lack of time for any preparation for filing for bankruptcy, but also the fact that most of the relief that is typically available to debtors was not available to Lehman, for two reasons. This is because, Miller argued, the most serious liquidity needs were with its broker-dealer, Lehman Brothers Inc. (LBI), an entity which could not be a debtor under Chapter 11. On the other hand, LBI, together with Lehman's fixed income division, were among the company's most valuable assets. However, 'its value depended on Lehman's ability to assure its clients and customers of its financial and operational integrity', which it was 'unable to do in the circumstances surrounding its bankruptcy.' 
Lehman also engaged in derivatives trading with some of the largest counterparties in the world, contracts representing another substantial asset for Lehman. Most of these contracts did not benefit from the protection of automatic stay.

Non-debtor counterparties to such contracts are allowed to exercise certain contractual rights triggered by the Chapter 11 case or financial condition. They have the right to terminate the contract and take advantage of positions in their favour and to leave in place contracts in which they owe money to the debtor. This caused a massive destruction of value for Lehman. ${ }^{10}$

On 15 September, the bankruptcy date, Lehman's derivative counterparties totalled about 930,000 , of which about 733,000 sought to terminate their contracts.

That was only part of the problem. Miller describes further practical issues, to which little attention was paid in the crisis-ridden days of September 2008. As more and more subsidiaries ran out of cash, and administrators, receivers and liquidators took over, each subsidiary was cut off from the others and Lehman Brothers Holdings Inc. (LBHI), the parent company, by the various jurisdictions. It was not possible to generate information and liquidate assets efficiently and identify ways to maximize value.

All the accumulated information in Lehman's systems totals 2,000 terabytes of data, an amount that would completely fill 20,000 computers to the maximum. This vast sea of information spreads across 2,700 software systems applications and is dispersed throughout ledger accounts in the numerous subsidiaries ... The financial information must be retrieved ... and collated and cross-referenced for accuracy and consistency. ${ }^{11}$

Regulators had not by that stage addressed this problem. It was only after the financial crisis that regulators addressed the issues of recovery and resolution procedures through the Financial Stability Board, the Basel Committee for Banking Supervision and the European Union. Amongst the lessons for the authorities which emerged from the collapse of Lehman, was the necessity for access to temporary liquidity. The provision of temporary liquidity for Lehman's broker-dealer, Lehman Brothers Inc., enabled an orderly transition to its acquisition by Barclays Capital.

After the financial crisis, international monetary institutions and regulatory authorities did address the problems involved in the failure of an internationally systemic financial institution by establishing agreed recovery and resolution 
procedures with particular reference to the removal of legal barriers to cooperation arising from the existence of different jurisdictions. ${ }^{12}$ The practical problems of the magnitude Miller describes remain.

\section{Did unwinding derivatives really destroy value?}

One of the key issues was whether or not a collapse of the magnitude of Lehman's and its role in the derivatives market caused disruptions and volatility in derivatives trading. The Bank for International Settlements (BIS) published a detailed report as part of its semi-annual reports tracking derivatives market data. The report for the second half of 2008 states that the

financial crisis in the second half of 2008 resulted in the first ever decline in the total notional amounts of OTC derivatives since data collection began in 1998. Notional amounts of all types of OTC contracts stood at around $\$ 592.0$ trillion at the end of December 2008, 13.4 per cent lower than their total of $\$ 683$ trillion six months before.

Against a background of severely strained credit markets and increased multilateral netting of offsetting contracts the volume of outstanding credit default swaps (CDS) contracts fell by 27.0 per cent to $\$ 41.9$ trillion. However, despite the lower outstanding volumes, the gross market value for CDS contracts increased by 78.2 per cent to $\$ 5.7$ trillion as a result of the credit market turmoil..$^{13}$

The notional amount of foreign exchange derivatives decreased by 21.0 per cent to $\$ 49.8$ trillion. Volumes of forward and forex swaps, which account for almost half of the total OTC FX derivatives in terms of notional amounts, declined by 23.1 per cent, while options volumes fell by 28.8 per cent. Currency swaps only contracted by 9.7 per cent, with the dollar and the euro remaining the most important currencies, followed by the yen and sterling. Commodity derivative markets also declined by two-thirds. These figures give some idea of the scale of the impact. Equity derivatives also fell sharply, in a sharp change from the first half of 2008, when they had risen by 20.1 per cent. OTC equity derivatives decreased by 36.2 per cent to $\$ 6.5$ trillion.

The figures paint a dramatic picture of the impact of the Lehman Brothers bankruptcy, as it 'triggered a confidence crisis ... one of the biggest credit events in history. ${ }^{14}$ The fall-out from the Lehman bankruptcy in the $\$ 57.3$ trillion CDS market was the most immediate concern, where Lehman had a central role 
as a major counterparty and reference entity. The bankruptcy would trigger default clauses in CDS contracts referencing Lehman and terminate contracts that the firm had entered into as a counterparty. This was why the special trading session was organized on Sunday 14 September, before the filing, which allowed the main CDS dealers to net out counterparty positions involving Lehman and to rebalance their books through the replacement of trades. Later, following ISDA (the International Swaps and Derivatives Association) procedures, an auction was conducted on 10 October to determine the recovery rate to be used in the cash settlement of CDS contracts, referencing Lehman and the net amount exchanged between parties. BIS notes that this set the recovery value at 8.625 per cent, based on quotes submitted by fourteen dealers. This bond price was only slightly lower than the bond price immediately before the auction.

Lehman's major source of funding was its issuance of commercial paper, to which money market funds were attracted because of their high credit ratings and yield premiums relative to US government paper. As noted previously, one of the funds, the public money market fund, Reserve Primary, "broke the buck' by falling below $\$ 1$ per share. The fund was liquidated and distributions made to investors as cash accumulated either through the maturing of portfolio holdings or their sale. This prompted massive runs on the other funds, leading to about $\$ 172 \mathrm{bn}$ worth of redemptions from the sector, which was worth $\$ 3.5$ trillion. The run stopped on 19 September 2008, when the US government introduced a temporary programme of insurance for money market investors. Even so, most funds reduced their holdings in commercial paper, as it was then deemed risky. A month later, the total value of outstanding commercial paper fell to $\$ 1.4$ trillion from $\$ 1.76$ trillion. The Federal Reserve began purchasing commercial paper on 26 October for the first time, which stabilized the market. By January 2009, the Federal Reserve held paper worth $\$ 357 \mathrm{bn}, 22.4$ per cent of the market, which it gradually reduced during that year.

The BIS Review provides another illustration of the legal problems in such a complex bankruptcy with filings in so many different jurisdictions. Lehman provided prime brokerage services to a large number of hedge funds, as a result of which hedge funds placed investment assets with Lehman's brokerdealer units in various jurisdictions. These assets were used as collateral for funding activities and were then reused by Lehman to meet its own obligations (re-hypothecation). The bankruptcy meant that many of Lehman's clients could not access their collateral assets during the whole process, whilst their assets changed value and they waited for the completion of differing legal processes. 
This would alter the size and location of hedge fund activities with their prime brokers, which together with attempts to reduce risk exposures, added to pressures in the funding and securities lending markets. On Sunday 21 September, as a result of the continuing concerns about counterparty risk and the unrelenting funding squeeze, Goldman Sachs and Morgan Stanley obtained permission from the US authorities to convert themselves into bank holding companies. This was designed to stop the transfers of counterparty positions and client funds to third parties, with CDS spreads for both credits tightening as a result. The BIS account of the immediate impact of Lehman's bankruptcy makes it even more astonishing that neither Chairman Bernanke nor Hank Paulson, who were in a position to understand the complex and interrelated effects such a sudden collapse would have, appeared to have any understanding of what was about to happen. It is true that some appropriate actions were taken immediately, but an immense amount of damage was inflicted both on America and the rest of the world, when a much smaller price might have mitigated the worst effects, even if it only took the form of temporary measures.

It is also important to disentangle the effects of the process of bankruptcies in New York and so many other jurisdictions from the bankruptcy itself. Here it is important to focus on the procedures set out by ISDA and to consider what contribution the Master Agreements were able to make to sorting out the enormous number and the wide range of derivatives, running into trillions of dollars.

\section{Did ISDA’s Master Agreements help to avert yet further catastrophe?}

For over twenty years, the over-the-counter swaps and other derivative contracts have been documented using the standard terms of the Master Agreements developed by ISDA. The first version was published in 1992 and the other in 2002. ${ }^{15}$ The 1992 version was the first to be designed in a form which applied to derivatives other than swaps and to allow for both financially and physically settled transactions. The 2002 version was revised as lessons were learned in the markets, and to reflect changes in the markets. New categories of transactions, such as credit derivatives and repos, were included in the definition of a 'specified transaction' for the purposes of default under a 'Specified Transaction Event of Default'. The term 'default' was also widened to cover a default under any credit support arrangement for the particular derivatives transaction. The 'Bankruptcy 
Event of Default' was modified to restrict the circumstances in which a grace period will apply and to reduce the grace period where it does apply. The market quotation and loss valuation methods were replaced by the close-out amount as a single valuation measure. The set-off clause was introduced to enable the nondefaulting party to set off any early termination amount against amounts owing to or from the defaulting party, whether or not arising from the ISDA Master Agreement. These are largely changes to events of default and termination events and changes to the mechanism for calculating termination payments after an early termination date and including a detailed set-off provision. The rules for interest on defaulted and deferred payments and compensation for interest on early termination and unpaid amounts were also then changed.

The ways in which the Master Agreements are applied in American and English law differ and make a difference to the settlement provisions for derivatives under the bankruptcy laws of each country. The underlying principle underpinning the US Bankruptcy Code is that the debtor's assets must be distributed in a fair and equitable way amongst the creditors. The policy is enforced by the 'automatic stay', that is the creditors of a bankrupt company cannot enforce their contractual rights against the debtor without the Bankruptcy Court's authorization, or unless there is a specific statutory exception. A series of amendments to the Bankruptcy Code from 1982 onwards allows for just such exceptions. These apply to securities contracts, commodities contracts, forward contracts, swaps agreements, repurchase agreements and master netting agreements, called 'qualified financial contracts' (QFCs). This was because these financial instruments, such as swaps, raise unique systemic issues. The automatic right of stay could mean that the non-defaulting counterparties were exposed to rapid changes in market conditions and interest rates over which they had no control and could lead to a series of settlement failures. ISDA had successfully argued over the years that a solvent counterparty's inability to immediately terminate its contract could interfere with its efforts to hedge and even jeopardize the counterparty's solvency. The reason for limiting the right of stay to such instruments was to preserve the stability of the financial system overall.

The principle underlying English solvency law is 'anti-deprivation'. This rule is based on the premise that the parties to an agreement cannot contract out of the mandatory provisions of legislation governing the distribution of an insolvent debtor's assets. These principles affected the way in which the bankruptcy was handled and the valuation of the derivative contracts.

The procedures, where one or other party defaults, require the termination of all contracts, which triggers the unwinding of all open contracts governed by the 
Master Agreement. Then the value of all contracts must be determined. The amounts owing or owed on individual transactions should be netted off to arrive at an aggregate sum, which one party owes the other - 'close-out netting' under the 2002 Master Agreement. Any net amount has to be paid. In the case of the bankrupt party, the amount is paid to the bankruptcy trustee or administrator. If an amount is owed by the bankrupt party, then that is a debt, which will have to be paid out of recoveries. This assumes that the non-defaulting party can close out its positions at market rates, and can then enter new positions to establish replacement hedges to avoid the risk of losses from changes in prices or rates.

What actually happened once Lehman Brothers Holdings Inc. filed for bankruptcy was that its status as guarantor for LBSF's derivative transactions meant that non-defaulting parties were able to elect to terminate their transactions, even though LBSF did not file for bankruptcy until 3 October 2008. Approximately 80 per cent of the derivatives counterparties to LBSF terminated their contracts under the ISDA Master Agreement within five weeks of bankruptcy. What happened then was that where the non-defaulting party owed LBSF money, that was paid, and if LBSF owed money to the non-defaulting party, that was not paid. Kimberley Summe, former Managing Director at Lehman Brothers Inc/Barclays Capital, reports that the Lehman estate was able to advance from its cash position of $\$ 7 \mathrm{~m}$. on 14 September 2008 , to $\$ 15$ bn by 1 February $2011{ }^{16}$ In other words, the Lehman bankruptcy did not have the disastrous effects that some had envisaged. Summe also quotes Daniel Ehrman, a managing director at Alvarez \& Marsal, who said, 'we discovered that out of all the claims against the Lehman estate, those in the derivatives subset were the most inflated'.

It is not easy to apply this methodology to more complex derivatives, where valuation will inevitably depend on factors such as the exact timing in a volatile market. It will also depend on the calculation agent and the calculation statement. The agreement allows the agent, often the dealer, to calculate the loss 'in good faith', taking into account all the relevant facts. If the dealer is the defaulting party, as in the case of Lehman, then conflicts and disagreements are very likely to occur, as indeed they did. The process, however, depends on the normal functioning of the market, allowing the non-defaulting party to re-hedge positions and to establish valuations with reasonable accuracy. Those with swaps found that they were unable to replace hedges in a reasonable time period and the large differences between the costs incurred and termination values under the ISDA procedures led to significant losses for the counterparties. At the time 
of its filing, Lehman had around 1.2 million derivative contracts open, with a notional face value of $\$ 39$ trillion. ${ }^{17}$ In September 2009, the court imposed a deadline for the settlement of about 6,000 derivative claims worth some $\$ 60 \mathrm{bn}$ payable by Lehman on the Lehman estate, including claims from forty of the largest US banks. There were operational issues as well. Market participants which had dealt with various Lehman entities had multiple ISDA Master Agreements in place, with different transactions recorded under each contract. Many of the counterparties' information systems had inaccurately grouped contracts together for netting and assessing net exposure, which made it difficult to determine the risks and the required hedging strategies.

The focus here is on the bankruptcy proceedings in the US and the way in which the automatic right of stay was suspended for derivatives. The safe harbour provisions of bankruptcy law can create perverse incentives for counterparties to jettison their contracts, when a debtor files for bankruptcy. This can create a run on the debtor's assets, as many counterparties terminate their contracts and seize any collateral securing those contracts. These incentives contribute to the systemic implications of a firm's failure, creating a stampede for exits, according to some analysts. Ayotte and Skeel, who argued for the removal of the blanket reversal of the automatic right of stay in the case of derivatives, pointed out that 'if the debtor is one of the handful of major derivative counterparties, the debtor's failure to could itself cause market-wide damage, since the glut of terminated contracts may overwhelm the market's ability to provide replacements. ${ }^{18}$

They point out that when Lehman filed for bankruptcy, the counterparties cancelled over 700,000 of the 930,000 derivative contracts, which threatened to create chaos, but the potential disruption was 'diminished somewhat by netting and the inability of many counterparties to retrieve assets to satisfy their claims. ${ }^{19}$ Some counterparties whose claims were collateralized could end their contract and use the collateral to meet Lehman's obligations. Counterparties without collateral were able to close out the contract, but they were free to take further steps to collect what they were owed. If they had been able to close out their contracts and to insist on immediate payment, then Lehman would have been forced to liquidate many of its assets. This would have further complicated the orderly resolution of the bankruptcy. Those without collateral can arrange to purchase an alternative hedge, but the principal cost is uncertainty as to the amount and timing of the payment in the debtor's bankruptcy case. If the contract is large, the costs of re-hedging could be prohibitive, but in many cases this was not the real problem. There were also standard procedures for determining their losses, and these were applied successfully in many cases. Some counterparties 
can terminate their contracts, but they will be vulnerable if they do not have collateral. That vulnerability gives counterparties a strong incentive to ensure that they are fully collaterized.

Ayotte and Skeel argue that the solution is to remove the exemption of derivatives from automatic stay which 'would strengthen counterparties' incentives to both carefully monitor the debtor and to avoid overexposing themselves to a single counterparty'. The costs of the automatic stay could also be reduced by setting deadlines on the debtor's decision on whether or not to retain the contract. ${ }^{20}$ In fact, it is not clear that the process of unwinding derivatives requires the removal of the automatic stay which some, including Ayotte and Skeel, have proposed. To understand that, it is necessary to see what actually happened to derivatives in the process.

It appears that the settlement of derivatives went ahead smoothly due to the use of the Master Agreements and exemption from automatic stay. Kimberley Summe stated that at the time of filing for bankruptcy, the Lehman estate reported that it was counterparty to 906,000 derivative transactions documented under 6,120 ISDA Master Agreements. The whole portfolio represented about 5 per cent of the global derivatives transactions at that time. In her article she states that 'approximately $80 \%$ of Lehman's derivatives counterparties terminated their transactions within five weeks of bankruptcy. Furthermore, none of Lehman's counterparties filed for bankruptcy nor did

the derivatives market grind to a halt after Lehman's bankruptcy filing ... In addition, while it was widely estimated in the lead-up to October 10, 2008 credit default swap auction for bonds referencing Lehman Brothers that close to $\$ 400 \mathrm{bn}$ could be required in payments to settle outstanding contracts, in fact only $\$ 6 \mathrm{bn}$ in net settlement payments were ultimately needed. ${ }^{21}$

A more detailed analysis was published in the Economic Policy Review in March 2014..$^{22}$ The advantage of this report is that the bankruptcy process is over and the results of most aspects of the process are known, since Lehman emerged from bankruptcy on 6 March 2012, although various legal cases were still pending then.

Some have argued that 70 per cent of the derivatives receivables worth $\$ 48 \mathrm{bn}$ were lost that could otherwise have been unwound. The alternative view is that the Lehman estate did not suffer any substantial loss on its derivative positions since the LBHI's counterparties initially overstated some of their claims, which were later overturned by the bankruptcy court. ${ }^{23}$ Duffie, Li and Lubke also pointed out that the use of novations enables counterparties to exit their 
positions by assigning them to other dealers, which depleted LBHI's cash reserves and therefore those of LBI since they were the main source of LBI's funding. This was the result of Lehman's original dealer counterparty, through novation, transferring its position to another dealer. As a result Lehman lost the associated 'independent amount' of collateral. This was not replaced because the initial margins were not posted as dealer-to-dealer trades. ${ }^{24}$

The OTC derivatives market was highly concentrated then, as shown by the fact that of the outstanding contracts in January 2011, the share of the thirty big bank counterparties was 85 per cent of the number of trades and 48 per cent of the derivative contracts by dollar value, but only 5 per cent of the number of contracts. Lehman and its counterparties had to negotiate an appropriate method for settling the remaining contracts. These banks, all affiliates of thirteen major institutions, were Bank of America, Barclays, BNP Paribas, Credit Suisse, Deutsche Bank, Goldman Sachs, JPM Chase, Merrill Lynch, Morgan Stanley, RBS, Societe Generale and UBS. The Lehman estate argued that the bank counterparties had submitted inflated claims, centring on the time and date of valuation; the method of valuation, for example, the use of the bid or ask price, as well as including additional amounts to the mid-market price; and set-off. The valuation of claims was made more difficult because of the 'replacement cost' methodology required by the Master Agreement, and the wide bid-offer spreads prevailing at the time. The progress of settling the claims was slow. A derivatives claims settlement framework was included in Lehman's January 2011 liquidation plan, but even that meant that Lehman had only settled with eight of the major financial firms at that time. Even by the beginning of 2013, about 1,000 derivatives contracts were still not settled. The Lehman estate argued that the need to carry out due diligence on numerous, complex claims on an individual basis was the chief cause of delay.

Problems occurred with some of the large contracts, such as Metavante and Nomura. The former had entered into a $\$ 600 \mathrm{~m}$. interest rate swap with Lehman Brothers Special Financing (LBSF), which required the company to pay 3.865 per cent p.a. to LBSF and receive three-month LIBOR in return. Metavante could have terminated the contract immediately after the Chapter 11 filing, but did not, refusing to make the required payments. The company was obliged to pay LBSF the difference between 3.865 per cent and the lower three-month LIBOR. If Metavante had ended the contract, it would have owed Lehman $\$ 6 \mathrm{~m}$., hoping that interest rates would rise, lowering the cost of ending the swap. The court ruled against Metavante and the issue was finally settled through mutual agreement. Other companies bringing cases against valuations included Nomura 
International, Nomura Securities and Nomura Global Financial Products. Finally, Lehman brought a case against Nomura in April 2010. Lehman finally abandoned its case against Nomura’s claim for $\$ 720 \mathrm{~m}$. in January 2012, and a settlement was reached out of court.

Various reasons for the delays in settlement have been put forward, but, echoing Harvey Miller's description of the structure of the company,

Lehman's organisational complexity resulted in delays. In many instances Lehman and its counterparties were uncertain of the identity of the specific Lehman entity against which creditors had claims ... Lehman's interconnectedness (in particular, guarantees by the holding company to affiliates) led to delays as holding company creditors argued in the hope of greater share of recovery than under strict priority rules. ${ }^{25}$

Further challenges followed, even with the well-defined and well-used process set out in the Master Agreements for assessing the value of terminated transactions. The process involves reconciling and reviewing counterparty valuations and then agreeing on a settlement. It is extremely demanding, owing to the duty of care imposed on the trustee, who has to review the methods by which each non-defaulting party reached its early termination amount for each derivative trade. With over 6,000 counterparties and about a million transactions to be considered, it is not surprising it took two years to settle 45.6 per cent of the claims.

Miller's point about the identity of Lehman's counterparties no doubt contributed to the problems of the bankruptcy, but the identification issues were becoming increasingly clear after the launch of the Depository Trust and Clearing Corporation's Trade Information Warehouse in November 2007, the repository of all derivatives trading details. Lehman was one of the participants in the launch, along with 200 other financial institutions, followed within a few months by a further 700 participants. All that information was available to regulators and others. It was also available during the bankruptcy proceedings, but the cause of the delays had more to do with valuation, and other practical and legal challenges. As Lehman's Financial Statements of November 2009 note:

Recoveries in respect of derivatives receivables are complicated by:

i. Whether counterparties have validly declared termination dates in respect of derivatives and lack of clarity as to the exact times and dates when counterparties ascribed values to their derivative contracts; 
ii. Abnormally wide bid-offer spreads and extreme liquidity adjustments resulting from market conditions as of the time when the vast majority of the company's derivatives transactions were terminated and whether such market conditions provide the company with a basis for invalidating counterparty valuations;

iii. Counterparty credit worthiness which can be reflected both in reduced actual cash collections from counterparties and in reduced valuations ascribed by the market to such counterparties' derivatives transactions and whether, in the latter circumstance, such reduced valuations are legally valid deductions from the fair value of derivatives receivables; and

iv. Legal provisions in derivatives contracts that purport to penalize the defaulting party by way of close-out mechanics, suspended payments, structural subordination in relation to transactions with certain special purpose vehicles, deductions for financial advisory and legal fees that the company believes are excessive and expansive set-off provisions.

Some of the non-defaulting counterparties who were out-of-the-money, and would have owed large sums to Lehman, if they had been in a position to pay, chose not to send in a termination notice. Some of these were municipalities and non-profits. They had issued floating rate bonds and entered into interest rate swaps where they paid a fixed rate and received a floating rate. Some of the swap counterparties were out-of-the-money to Lehman as the fixed rate was higher than the floating rate before Lehman's bankruptcy. Naturally Lehman wanted to settle these potentially valuable contracts, and considered that market movements might reduce the amount owed. Lehman and its counterparties failed to agree on valuations, partly because the markets were illiquid. These claims are determined by replacement costs, which diverged from fair market value because of the large bid-offer spreads at that time. Lehman asked the court to approve procedures to allow the valuation of non-terminated contracts by assigning them to third parties with the consent of unsecured creditors and the counterparty. The effect of this was to encourage the use of already established dispute resolution procedures. By January 2009, there were 2,667 out of over 6,000 contracts of this kind at the time of the bankruptcy. By 17 June 2009, only 17 per cent of the contracts and less than 1 per cent of the trades were not terminated.

Despite these complications, and special pleading on the part of the large banks, while the valuation of derivatives and the settlement of claims took time, they did not cause the disruption to the markets that many had feared. The settlement of claims took time for different reasons for the varying groups 
of contracts outstanding at the time. The Lehman estate took steps to speed up the process. On 25 January 2011, Lehman amended its liquidation plan and proposed to reallocate payments owed to derivative counterparties to creditors of the parent company. As a result, LBSF transferred $\$ 7.35 \mathrm{bn}$ in cash and investments, to add to LBHI's $\$ 2 \mathrm{bn}$. This proposal coincided with the estate's decision that the defaulting party should rely on a standardized methodology to value remaining derivative claims. This was approved on 6 December 2011. The first distributions to creditors were made on 17 April 2012. Summe concludes that the 'allegations that derivatives destroyed value is flatly at odds with the fact that derivatives were the biggest contributor to boosting recoveries for Lehman's creditors. ${ }^{26}$

The adoption of the Joint Chapter Plan on 6 December 2011 did not entirely resolve the issue of derivative claims by the large banks, but the claims and counterclaims had more to do with the activities of the parties to the disputes than with the actual nature of the contracts. Summe's detailed analysis does not support the view that the process itself caused the destruction of value. Nor does that proffered by Fleming and Sarkar. Summe notes that 'Lehman's organisational complexity resulted in delays. For example, in many instances, Lehman and its counterparties were uncertain of the identity of the specific Lehman subsidiary against which creditors had claims. ${ }^{27}$ All that means is that a preplanning phase would have taken longer anyway. The authors conclude that the 'predictability of Lehman's claims and settlement procedures were hindered by the novelty of the business and financial structure', and by the fact, that, although existing case law provided a useful starting point for Lehman's resolution, the court provided new interpretations of the Bankruptcy Code (for example, regarding some aspects of the safe harbour provisions for derivatives). This reflected the 'prominence of complex financial scenarios that the bankruptcy court had to analyse perhaps for the first time. ${ }^{28}$

The above analyses were not taken into account by regulators, policymakers or lawmakers alike. It was argued that the Bankruptcy Court was too slow and expensive as a means of dealing with the bankruptcy of a major financial institution. The Orderly Liquidation Authority (OLA) was introduced as Title II of the Dodd-Frank Act. The new authority requires the Secretary of the Treasury to obtain the consent of the board in order to act, and if he fails to get their consent, he has to obtain the approval of the court, for which a period of twenty-four hours is allowed. Financial institutions have to provide 'living wills' designed to prepare for handling a distressed company, which would then have the ability to borrow from the Federal Reserve for debtor-in-possession 
funding. The OLA would also be authorized to draw on the Federal Reserve to finance a bridge financial company, one of the purposes of which would be to support the collateral of the failed company's derivatives. Title II, however, only allows for a one-day stay on ipso facto clauses after which a derivatives contract terminates and can be closed out. Title II gives the government considerable power and discretion to intervene, take over and liquidate financial companies without any time allowed for judicial review or analysis, and puts the power to handle the process in the hands of the Federal Deposit Insurance Corporation. In the eyes of many, the FDIC lacks the ability to run such a liquidation process in a predictable rule-like manner. If Title II had been in place for any failed 'systemically important' financial company, it is unlikely that the OLA would have resulted in any substantial change in the way in which derivative trades are handled post-bankruptcy. Together with the requirement that derivative contracts are placed at clearing houses, the risk is that the clearing house would have to be bailed out by the government as well. The issue of who bears the losses in the event of failure: the clearing houses, their member banks, investors or governments, is one which is now occupying the minds of all the players. The OLA has, of course, yet to be tested, but its necessity has not been proved by the handling of derivatives in the Lehman bankruptcy process.

Nor did the fault lie with derivatives themselves, but rather with the fact that the derivatives were derived from the subprime mortgages, and that is where the destruction of value was to be found. Derivatives traded between 'sophisticated parties' were not regulated, except as part of the general 'safety and soundness' overseen by the regulators of banks and securities firms. ${ }^{29}$ Alan Greenspan, giving testimony at a Senate hearing in 2000, quoted with approval the report of the President's Working Group of which he had been a member, stating that

regulating financial over-the-counter derivatives, involving professional counterparties was unnecessary ... as financial derivatives are not readily subject to manipulation and because professional counterparties can protect themselves against fraud and unfair practices. ${ }^{30}$

The Act effectively removed a wide range of derivatives, including credit default swaps, futures, options, mortgage-backed securities and collateral default obligations, from regulation. In effect, it meant that the OTC market was exempt from capital adequacy requirements, reporting and disclosure, opening the way for excessive speculation. 


\section{Too big to manage?}

Inevitably, in the aftermath of the financial crisis, regulators turned their attention to capital, liquidity and supervision, in order to prevent the failures of what then became known as 'systemically important financial institutions' (SIFIs). This resulted in new capital and liquidity requirements and an increased regulatory focus on macro-prudential surveillance and the development of specific tools to address the build-up of systemic risk in the financial system. Individual large banks are now required by the regulators to produce recovery and resolution plans outlining detailed plans for the way in which they would regain viability if they were under severe financial stress. The plans, often called 'living wills', require extremely detailed information from the banks, which has to be updated regularly. The full details are not released publicly, since this would indeed defeat the object if they were released before or during a financial crisis. It is, however, unlikely that such plans would ensure the orderly wind-down that regulators envisaged, given the difficulty of identifying and predicting risk, problems of confidentiality with the additional possibility of loss of experienced and skilled staff if they knew that, in a crisis, their business unit would be one of the ones to be sacrificed. That is linked to market reactions to the immediate prospect of an orderly winding down of a particular bank. In other words, it would not prevent the kind of 'bank run' which is part of the explanation of what happened to Lehman. If the market is strong, then the possibility of rescuing an individual bank is higher, but living wills cannot resolve systemic problems that affect all SIFIs market-wide, such as a sudden sharp rise in interest rates or sovereign defaults.

However, even if recovery and resolution plans do not serve the purpose for which they were intended in the next crisis, they may play a part in fending off another crisis. The issue which has been neglected too often in the focus on 'too big to fail' is the issue of 'too big to manage' or better, 'too complex to manage.' The analysis of the Lehman bankruptcy proceedings revealed the complexity and hence the lack of transparency in the bank's structure which impeded progress and may also have led to a lack of fairness in the way in which creditors were repaid.

In 2008, when Lehman Brothers collapsed, regulators found it next to impossible to identify all the counterparties that were exposed to the bank and, in turn, to each other. Senior policymakers had to hold their collective breath when that and other major Wall Street events took place, because they had no reliable way of determining who would be affected and in what way. ${ }^{31}$ 
Too many others experienced the same difficulties at that time.

The OCC recognizes that

one potential obstacle to risk management and corporate governance is the multiplicity of legal entities within banking organizations ... [These] add greatly to the complexity of the company and measurably increases the difficulty of managing it. ${ }^{32}$

As a result, banks are reducing the number of legal entities within their organizations, which will benefit the banks in terms of reducing legal, accounting and other costs, and provide other benefits in terms of system integration.

This goes part-way towards the recognition that the informational requirements for living wills are likely to be much more useful for regulatory supervision and management of the whole enterprise by the banks. The extensive detailed information as set out, for example, by the UK Prudential Regulatory Authority (PRA) and the Bank of England, should provide the basis for banks to design an appropriate management and management information structure as the basis for risk management procedures. The bankruptcy proceedings served to highlight both the complexity of Lehman and the lack of management information systems, enabling one part of the bank to communicate with another. At times, the suspicion arises that the holding company in New York simply received the cash at the end of the business day, without knowing enough about the circumstances in which the money was earned. At the very least, the complexity adds to the difficulty of management.

The role of large banks in the financial crisis prompted many to argue that there is an optimal size of banks or that the range of activities of banks should be restricted (the Volcker rule). ${ }^{33}$ The argument is that market-based activities and organizational complexity increase systemic risk but not the individual bank risk. This implies that it is not possible to look at any one bank in isolation but that the connections between them may well increase systemic risk. It is quite clear that the connections between both the 'big five' investment banks and banks throughout the world and Lehman Brothers were not understood either by the regulators or by Hank Paulson, although he was formerly the chief executive of Goldman Sachs, and others, during that fateful summer of 2008. When large banks fail, 'they are more likely to fail together precisely because they are more interconnected through asset and short-term lending. ${ }^{34}$ However, the study fails to recognize the significant risks to the ability to manage posed by over-complex banks. 
Size and complexity are not always a disadvantage; indeed, there may be value in having multiple business units and operating on a global scale. However, managing a complex business by simplifying the organization's business structure is essential. Making sure that the accountability lines are clear and deciding to withdraw from certain markets, dropping unprofitable business lines or those which require the investment of too much time, money and effort are the routes to success. Charles Taylor of the OCC observed that 'banks going through the legal entity simplification process are the ones making noticeable progress in meeting our heightened expectations around risk management and governance. ${ }^{35}$ Large and complex banks can only be well-managed if the role and responsibilities of senior management are clear and the board oversight is both competent and independent. The role of the board in risk management and in retaining value is considered in Chapter 9. 